\title{
Hypomyopathic Dermatomyositis with Refractory Dermatitis Treated by Low-dose IL-2
}

\author{
Miao Miao (D) $\cdot$ Yuhui Li $\cdot$ Bo Huang $\cdot$ Jing He (D) $\cdot$ Zhanguo Li (D)
}

Received: June 1, 2020 / Published online: July 9, 2020

(C) The Author(s) 2020
Keywords: Hypomyopathic dermatomyositis; Refractory dermatitis; Low-dose IL-2

\section{Key Summary Points}

A patient with hypomyositis dermatomyositis presenting with refractory cutaneous lesions failed to respond to long-term standard therapy.

Low-dose interleukin-2 (IL-2), which is an effective treatment for various autoimmune diseases, was also effective in this patient with intractable skin lesions.

The clinical improvement by low-dose IL2 was associated to improvement of immune system imbalance by increasing Treg cell proliferation and decreasing the level of Th17 cells.

\section{INTRODUCTION}

Hypomyopathic dermatomyositis (DM) is a rare form of dermatomyositis with autoimmune features based on serological characterization. The abnormal immunological distribution of circulating $\mathrm{CD}^{+} \mathrm{T}$ cell subsets in hypomyopathic DM is similar to that found in classic DM. Previous studies have proven that Th17 cell

Peking-Tsinghua Center for Life Sciences, Peking University, Beijing, China 
levels are increased and those of Treg cells are decreased in DM [1]. Low-dose interleukin-2 (IL2) is a proven effective treatment for DM, inducing Treg cell proliferation and suppressing Th17 cell level [1-3]. Consequently, immunoregulation driven by low-dose IL-2 represents a potential therapy to maintain selftolerance in autoimmune diseases [3]. However, to date, there has been no report of the effect of IL-2 treatment on hypomyopathic DM.

Most patients with skin disease respond to the initial therapy, and some achieve sustained disease control either off all therapy or with low-dose maintenance therapy. Patients who fail to respond to conventional interventions or who relapse after an initial response have refractory disease and require the initiation of more aggressive therapies [4, 5]. Here, we describe a patient with hypomyopathic DM with refractive dermatitis. She failed to respond to conventional therapy and was subsequently treated with low-dose IL-2 to which she did respond.

The patient provided informed consent to participate in the study and to allow her patient details to be collected for the purpose of publication. She gave consent for the publication of this article.

\section{CASE PRESENTATION}

A 61-year-old women developed redness in the extension of the proximal interphalangeal (PIP) joint and metacarpophalangeal (MCP) joint. The patient also developed rough skin and desquamation with itching around the extension of PIP, the sides of the palms of the hands, the elbow joints and the feet. She had no history of infectious or chronic diseases, and there was no presentation of myalgia, weakness, wheezing or fever. Laboratory tests revealed positivity for anti-ANA and anti-SSA antibodies and for rheumatoid factor. She was initially treated with prednisone $0.5 \mathrm{mg} / \mathrm{kg} /$ day and hydroxychloroquine (HCQ) $200 \mathrm{mg}$ twice a day, and the skin lesions ameliorated slightly within 6 months.

In the last month of the prednisone/HCQ treatment, there was a gradual aggravation of redness of the skin around the eyes and of the areas of rough skin. There was weakness of proximal lower limb muscles, but no myalgia, swallowing difficulties or chest pain. Creatine kinase (CK) level was not increased, and laboratory testing revealed positivity for anti-PL-7, anti-TIF1 $\gamma$ and anti-Ro-52 antibodies. A positron emission tomography-computed tomography scan and tests for tumor markers, including carbohydrate antigen, carcinoembryonic antigen and alpha-fetoprotein, were performed, with no internal malignancy found. Treatment with HCQ was continued, with the addition of IL-2 $10^{6}$ IU administered subcutaneously once weekly. Within 1 week of treatment initiation with IL-2, the rash on the hands and elbows improved, and after 2 months all tests for autoantibodies were negative.

However, her strength declined in the following period. The CK level did not increase but the lactate dehydrogenase level did increase slightly. Magnetic resonance imaging and electromyography studies of the muscles did not reveal any obvious positive findings, but muscle biopsy showed MHC-I-positive fibers along the fasciculus. A diagnosis of hypomyopathic DM was further confirmed with the exclusion of other complications. Cyclosporin A (CsA) $100 \mathrm{mg} /$ day $(2 \mathrm{mg} / \mathrm{kg})$ and prednisone $1 \mathrm{mg} /$ $\mathrm{kg} /$ day (50 mg/day) were added to the treatment regimen, which led to amelioration of the muscle weakness of the lower limbs within 1 week of treatment initiation. The prednisone was reduced to $5 \mathrm{mg}$ per week (from 50 to $30 \mathrm{mg} /$ day), then to $5 \mathrm{mg} /$ day every other week (from 30 to $20 \mathrm{mg} /$ day). Once prednisone had been reduced to $20 \mathrm{mg} /$ day, weakness of the lower muscles and rough skin on both hands flared. Therefore, the dose of IL-2 was increased to $10^{6} \mathrm{IU}$ twice weekly, and the above symptoms disappeared within 1 week. The patient is currently on a treatment regimen of prednisone $10 \mathrm{mg} /$ day, CsA $100 \mathrm{mg} /$ day, IL-2 $10^{6} \mathrm{IU}$ twice weekly and HCQ $400 \mathrm{mg} /$ day. At the time of writing of this case report, the patient has been symptom free for 8 months. Treatment with low-dose IL-2 resulted in an increase in Treg cells and a decrease in Th17 cells and the Th17:Treg ratio (Fig. 1a-c). No adverse side effects were observed during IL-2 administration. 

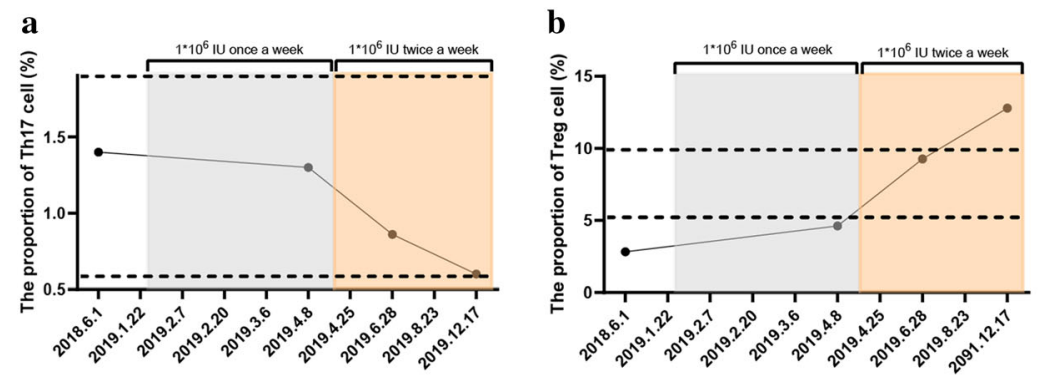

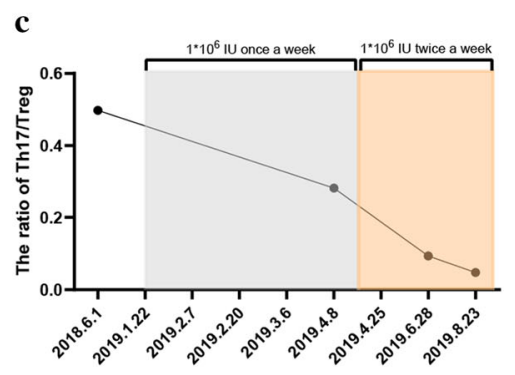

Fig. 1 Th17 (a) and Treg (b) cell levels and Th17:Treg ratio (c) prior to initiation of treatment with interleukin-2 (IL-2) (white background), with treatment with IL-2 $10^{6}$ IU administered subcutaneously once weekly (gray

\section{DISCUSSION}

We describe a patient with refractory and recurrent dermatitis of hypomyopathic DM successfully treated by low-dose IL-2. Treg cells are critical for the suppression of an excessive immune and inflammatory response and can serve as a hallmark of immune tolerance [4]. Immune intolerance caused by quantitative and/or qualitative deficiencies of Treg cells is now regarded as the pivotal origin of autoimmune diseases [2]. Our patient had increased Treg cells, decreased Th17 cells and a reduced Th17/Treg ratio during her treatment with IL-2. Both her symptoms and immunological cell levels ameliorated after the treatment. The improvement in her dermatitis was associated with the rebalance of Treg and Th17 cells.

The patient did not respond well to HCQ and CsA. Low-dose Il-2 has been proven to be an effective treatment for DM [1-3] and is safer than immunosuppressants in terms of cytotoxicity and infection. The safety of low-dose IL-2 has been shown by a number of previous studies. Its use is not associated with severe side effects, a reduced risk of infection has been shown $[6,7]$.

\section{CONCLUSIONS}

Low-dose IL-2 is effective and safe for treating hypomyopathic DM, especially for refractory cutaneous lesions. background) and with treatment with IL-2 $10^{6}$ IU administered subcutaneously twice weekly (light-brown background)

\section{ACKNOWLEDGEMENTS}

We thank the patient whose treatment was reported in this study.

Funding. No funding or sponsorship was received for this study or publication of this article. The journal's Rapid Service Fee was funded by the authors.

Authorship. All named authors meet the International Committee of Medical Journal Editors (ICMJE) criteria for authorship for this article, take responsibility for the integrity of the work as a whole, and have given their approval for this version to be published.

Disclosures. Miao Miao, Yuhui Li, Bo Huang, Jing He and Zhanguo Li have nothing to disclose.

Compliance with Ethics Guidelines. The patient provided informed consent to participate in the study and to allow her patient details to be collected for the purpose of publication. She gave consent for the publication of this article.

Open Access. This article is licensed under a Creative Commons Attribution-NonCommercial 4.0 International License, which permits any non-commercial use, sharing, adaptation, distribution and reproduction in any medium or format, as long as you give appropriate credit to the original author(s) and the source, provide 
a link to the Creative Commons licence, and indicate if changes were made. The images or other third party material in this article are included in the article's Creative Commons licence, unless indicated otherwise in a credit line to the material. If material is not included in the article's Creative Commons licence and your intended use is not permitted by statutory regulation or exceeds the permitted use, you will need to obtain permission directly from the copyright holder. To view a copy of this licence, visit http://creativecommons.org/licenses/by$\mathrm{nc} / 4.0 /$.

Open Access. This article is licensed under a Creative Commons Attribution-NonCommercial 4.0 International License, which permits any non-commercial use, sharing, adaptation, distribution and reproduction in any medium or format, as long as you give appropriate credit to the original author(s) and the source, provide a link to the Creative Commons licence, and indicate if changes were made. The images or other third party material in this article are included in the article's Creative Commons licence, unless indicated otherwise in a credit line to the material. If material is not included in the article's Creative Commons licence and your intended use is not permitted by statutory regulation or exceeds the permitted use, you will need to obtain permission directly from the copyright holder. To view a copy of this licence, visit http://creativecommons.org/licenses/by$\mathrm{nc} / 4.0 /$.

\section{REFERENCES}

1. Zhang SX, Wang J, Sun $\mathrm{HH}$, et al. Circulating regulatory $\mathrm{T}$ cells were absolutely decreased in dermatomyositis/polymyositis patients and restored by low-dose IL-2. Ann Rheum Dis. 2019. https://doi.org/ 10.1136/annrheumdis-2019-216246.

2. Rosenzwajg M, Lorenzon R, Cacoub $\mathrm{P}$, et al. Immunological and clinical effects of low-dose interleukin-2 across 11 autoimmune diseases in a single. Open Clin Trial Ann Rheum Dis. 2019;78(2):209-17.

3. Feng M, Guo $\mathrm{H}$, Zhang C, et al. Absolute reduction of regulatory $\mathrm{T}$ cells and regulatory effect of short-term and low-dose IL-2 in polymyositis or dermatomyositis. Int Immunopharmacol. 2019;77:105912.

4. Vuong V, Duong TA, Aouizerate J, et al. Dermatomyositis: factors predicting relapse. J Eur Acad Dermatol Venereol. 2016;30(5):813-8.

5. Wolstencroft PW, Chung L, Li S, et al. Factors associated with clinical remission of skin disease in dermatomyositis. JAMA Dermatol. 2018;154:44-51.

6. He J, Zhang R, Shao M, et al. Efficacy and safety of low-dose IL-2 in the treatment of systemic lupus erythematosus: a randomised, double-blind, placebocontrolled trial. Ann Rheum Dis. 2020;79(1):141-9.

7. Humrich JY, von Spee-Mayer C, Siegert E, et al. Lowdose interleukin-2 therapy in refractory systemic lupus erythematosus: an investigator-initiated, single-centre phase 1 and $2 \mathrm{a}$ clinical trial. Lancet Rheumatol. 2019;1(1):e44-54. 